\title{
SEASONAL ABUNDANCE OF PARLATORIA BLANCHARDII (TARG.-TOZZ.) AND THE ASSOCIATED PARASITOID PETEROPETRIX AEGYPTICA ON DATE PALM IN QALIOBIYA GOVERNORATE
}

\author{
SAHAR A. ATTIA \\ Plant Protection Research Institute, ARC, Dokki, Giza \\ (Manuscript received 24 March 2015)

\begin{abstract}
$\mathrm{S}$ easonal abundance of Parlatoria blanchardii (Targ-Tozz) and the associated parasitoid Peteropetrix aegyptica were studied for two successive years (2012-2013) \& (2013-2014) on date palm in Qalio1biya Governorate. The obtained results revealed that $P$. blanchardii found on date palm trees all over the year and had four overlapping generations per a year. The $1^{\text {st }}$ generation started from $1^{\text {st }}$ July to $1^{\text {st }}$ October (summer) with duration of 3-3.5 months, the $2^{\text {nd }}$ started from mid October to mid January (winter), its duration was 3.5-4 months, the $3^{\text {rd }}$ generation started from $1^{\text {st }}$ February till mid April (late winter), its duration was 3 months and finally the $4^{\text {th }}$ generation started from $1^{\text {st }}$ May till mid June (spring). The second year of study had nearly the same result. Peteropetrix aegyptica was a primary parasitoid recorded associated to Parlatoria blanchrdii and had four periods of activity per a year. The highest period was recorded in summer in the first year but it recorded in winter during the second one. Rate of parasitism during the second year was higher than the first year. One Climatic factors (Min, Max. Temp. \& R. H.) give positive highly significant correlation with the pest different stages. Multiple regression was insignificant except Min. Temperature which proved positive and highly significant. Also the combined effect of the three climatic factors was positive and significant. The changes in the half monthly count of the nymph, adult, gravid females populations related to the effect of the tested weather factors were $91.02,92.36 \& 90.3 \%$, respectively during the first year and 95.76 , $86.74 \& 80.95 \%$, respectively during the second year of study.
\end{abstract}

\section{INTRODUCTION}

Date palm Phoenix dactlifera L., (Fam. Palmaceae) is one of the most important horticultural crops in Egypt. Cultivation of date palm trees in Egypt goes back to thousands of years. (Loutfy, 2010). Date palm is subjected to infestation with a variety of insects, some of which may rank to serious pests. Among these pests are scale insects, mealy bugs, lepidopterous larvae and adults. Frequent observation reveals that the scale insect Parlatoria blanchardii (Tatg.-Tozz.) order Homoptera, suber family (Coccoidea, Fam. Diaspidae), proved to be one of the most important insect pests which infest date palm trees in Qaliobiya Governorate. Immature and 
mature females scale insect often occur on the various parts of offshoots and palm (El-Said, 2000). This pest sucks the plant sap causing weakness of the tree and deformations by the action of the toxic saliva. Severe infestation causes the drying out of the branches and cortical lesions form, yellow and dropping and distortion of the foliage and fruit blossoms, tumor formation, deterioration of palm and flower abscission, leaf rolling, chlorosis leaf dropping, shoot twisting and strong malformation of fruits. So that, the quality and quantity of date fruit yield are significally affected or decreased (El-Sherif et al.,1998,El-Said, 2000, Abivardi, 2001, El-Sayed, 2007 and Blumberg, 2008) Therefore, the present investigation was oriented towards studying the seasonal fluctuation of the scale insect Parlatoria blanchrdii and the associated parasitoid Pteroptrix aegyptica Evas and Abd- Rabou (Hymenoptera: Aphelinidae) .

\section{MATERIALS AND METHODS}

The present work was carried out in a date palm orchard at Qaliobiya Governorate Shebeen El-kanater area, throughout two successive years started from $1^{\text {st }}$ July 2012 till mid June 2014, to determine the seasonal fluctuation in the population density of the Parlatoria blanchardii (Targ.-Tozz.) and the associated parasitoid Peteropetrix aegyptica . Four palms of almost similar age, vegetation and height were chosen for sampling which was conducted at half-monthly intervals. Samples of 30 leaflets (10 leaflets $\times 3$ replicates) were picked out from the date palms. The samples were put in polyethylene bags and transferred into laboratory for inspection with stereomicroscope; the insects on each sample were sorted into

1- Alive unparasitized individuals which were as follow:

Nymphs, adult female and gravid females (ovipositing female). The total number of the alive individuals in each sample was taken as the population index.

2- Parasitized individuals which were as follow:

Larvae of the parasitoid, pupae of the parasitoid and the rate of parasitism was calculated according to the formula of Orphanides (1982):

\section{No. parasitized scale insects}

\section{$\%$ Parasitism =}

Total No. parasitized and non parasitized scale insect

The number of annual generations and their durations of $P$. blanchardii were estimated by applying Jacob (1977) formula, through out the two successive years of investigation. 


\section{RESULTS AND DISCUSSION}

\section{1- Population fluctuations:}

Figs. (1\&2) show the half-monthly population fluctuations of the nymph, adult female and gravid female stages and total population of Parlatoria blanchardii at Qaliobiya Governorate in 2012-2013 \& 2013-2014 seasons.

1- Seasonal fluctuation of total population. The total population of $P$. blanchardii had four peaks per year, during the first year of study the peaks were recorded in early September, early December, early January and early June with 1597, 677, 633 \& 1374 insect/leaflet. During the second year of study the four peaks recorded in late summer (mid September) with 708 insect/leaflet, autumn (early November) with 169, winter (early February) with 280 insect/leaflet finally the fourth one recorded in spring season (mid May) with 838 insect/leaflet.

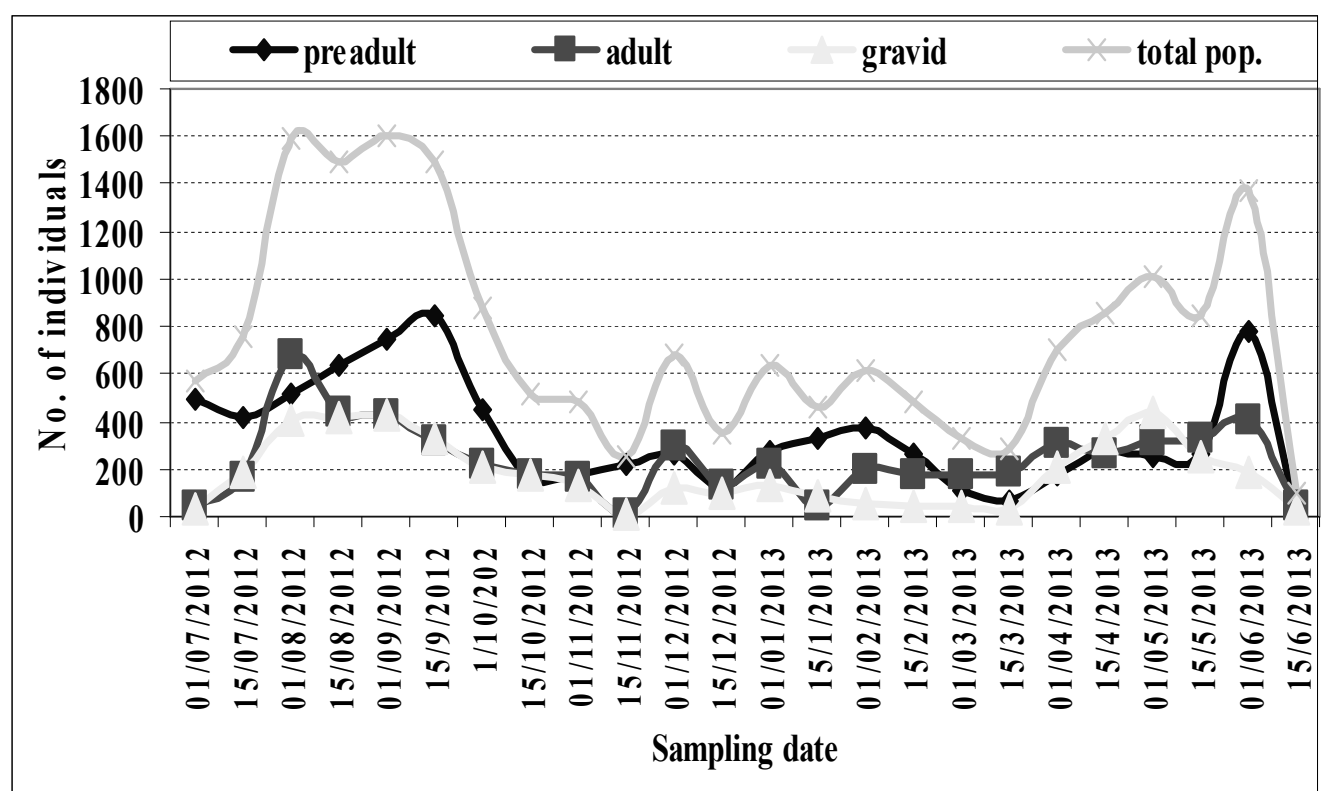

Fig. 1. Seasonal fluctuations of Parlatoria blanchardii total population and different stages during 2012-2013. 


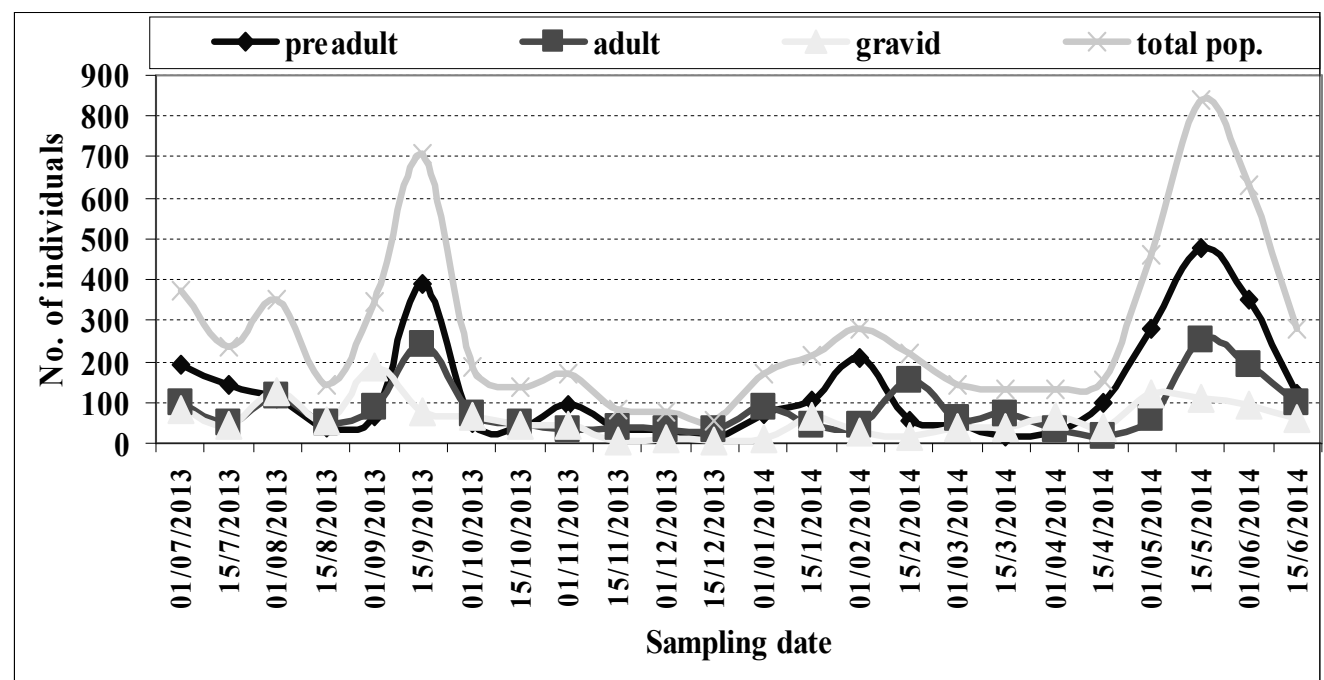

Fig. 2. Seasonal fluctuations of Parlatoria blanchardii total population and different stages during 2013-2014.

\section{2- Different stages of Parlatoria blanchardii.}

a- seasonal fluctuation of nymphal stage. Data illustrated in Fig. (1) showed that nymphal stage had four peaks per year occurred in mid September, early Decemder, early February and early June with mean number of $(848,267$, $368 \& 781$ nymph/leaflet) respectively during the first year of study. Also there were four peaks of nymphal stage during the second year of study in mid September, early November, early February and mid May with mean number of $(388,95,210 \& 479$ nymph/leaflet) respectively.

b- Seasonal fluctuation of adult stage. The same figure showed that, adult female had three peaks per year. During the first year these peaks were 681adult female, the highest one in early August, 292 adult female/leaflet in early December,308 adult female/leaflet in early April and finally 401adult female/leaflet in early June. During the second year the population was lower than the first year where the peaks were $(117,242,151 \& 250$ adult female/leaflet) recorded in early August and the mid of (September, Fibruary \& May) respectively.

c- Seasonal fluctuation of gravid females. Data in the same figure showed that, the gravid females had three peaks per year of study and also the population of the second year was lower than the first year. The peaks of the first year were recorded in $1^{\text {st }}$ September with 425 gravid female/leaflet, early January with 133 gravid female/leaflet and $1^{\text {st }}$ May with 441 gravid female/leaflet. In addition, the three peaks of the second year recorded in early September, mid January and early May with population of $189,65 \& 120$ gravid female respectively. 
During these periods of the peaks the climatic factors (Min, Max temperature $\& \%$ Relative humidity) were suitable and the studied pest fluctuated according to the phonology of the date palm tree.

Finally from the preceding study it could be concluded that the Parlatoria blanchardii had four seasonal activity periods, the highest periods recorded in spring and late summer or autumn because of the favorable climatic factor which ranged between $\left(16.5-22.7^{\circ} \mathrm{C}\right)$ Min., $\left(20.8-32^{\circ} \mathrm{C}\right)$ Max temperature and $(40.28-64.08 \%)$ relative humidity and also depend on the activity of the tree, when the tree was vigor and full of sap the activity of the pest was increased.

These results are agree with, Avidov \& Harpaz (1969) they mentioned that, in middle east, the crawler population of $P$. blanchardii peaked tree times a year in February, May and October-November and also agree with Hussain (1996) who showed that the population density of the same pest on date palms at Bharia oases had three distinct peaks in October, March and July, whears in Giza the three peaks occurred in November, February and May, Kehat et al. (1974) reported that the population of this insect was increased during spring and autumn, Bakry (2014) stated that Parlatoria blnchardii total population and different stages had four peaks per a year in Esna district, Luxor Governorate.

\section{Number and duration of the annual generations.}

Data of the half monthly counts of nymphal stage of Parlatoria blanchardii on date palm leaflets in Qaliobiya Governorate during 2012-2013 and 2013-2014 were used to estimate number and durations of annual field generations.

Figs. (3\&4) indicated that $P$. blanchardii had four overlapping generations per a year as follows

\section{Generations of the first year of study,}

1- The first generation: It started from the first of July (2012) till, $1^{\text {st }}$ October with the duration of three months and half its peak was 848 nymph/leaflet. This generation was the highest peak. These results due to the suitable and high climatic factors which ranged between, Min. $\left(21.5-24.82^{\circ} \mathrm{C}\right)$, Max. tempratures (31.88-35.70 C) \& R. H. (49.07-59\%).

2- The second generation: It began from mid October and end at mid January its period was 3.5 months, and its peak was 276 nymph/leaflet. The climatic factors ranged between Min. $\left(9.21-21.36^{\circ} \mathrm{C}\right)$, Max. $\left(17.36-30.36^{\circ} \mathrm{C}\right)$ temperature and R.H. (51.62-64.07\%).

3- The third generation: started from $1^{\text {st }}$ February till mid April, with the duration period of three months and its peak was 368 nymph/leaflet. During this 
generation the climatic factors recording Min.temp. (10.93-15.14 $\mathrm{C})$, Max. temp. $\left(19.94-20.86^{\circ} \mathrm{C}\right)$ temperatures and R. H. (39.07-51.00\%).

4- The fourth generation: which was the shortest one with duration of 2 months started from $1^{\text {st }}$ May to mid June its peak was 781 nymph/leaflet, climatic factors ranged between Min. temp. $\left(15.31-21.12^{\circ} \mathrm{C}\right)$, Max. temp. $\left(27.19-32.76^{\circ} \mathrm{C}\right) \& \mathrm{R} . \mathrm{H}$. (37.47-56.00\%).

During the first year the parasitoid number and rate of parasitism were low to effect on number and duration of $P$. blanchrdii genertions.

\section{Generations of the second year of study.}

1- The first generation: Started from early July 2013 till mid September 2013, its duration was three months and its peak was 388 nymph/leaflet. The climatic factors ranged between Min. $\left(22.21-23.93^{\circ} \mathrm{C}\right)$, Max. temperature $\left(32.29-34.57^{\circ} \mathrm{C}\right)$ and R. H. (51-59.71\%), also rate of parasitism ranged between (0.28-11.66\%)

2- The second generation: It was the lowest one and started from early October till mid January 2014 with duration of four months and its peak was 95 nymph/leaflet. The climatic factor ranged between Min. $\left(9.13-21.44{ }^{\circ} \mathrm{C}\right)$, Max. temperature $\left(18.21-31.44{ }^{\circ} \mathrm{C}\right)$ and R.H. $(51.44-66.93 \%)$, when the rate of parasitism ranged from 0.00 to $22.66 \%$.

3- The third generation: Occurred from early February to the mid of April, it elapse about 3 months, with a moderate peak (210 nymph/leaflet) under field condition Min. (10.5-14.93ㅇ), Max. $\left(19.42-26.71^{\circ} \mathrm{C}\right)$ \& R.H. (45.7-60.71\%) while rate of parasitism ranged between (1.90-18.19\%).

4- The fourth generation: Permanency about 2 months, it was the shortest and highest one which started from first May to the end of the year of study, its peak reach to 479 nymph/leaflet and field conditions were, Min. (17.84-21.54 $\left.{ }^{\circ} \mathrm{C}\right)$, Max. temperature $\left(30-32.79^{\circ} \mathrm{C}\right)$, R.H.(40.29-45.75\%) and rate of parasitism were (0.59-3.42\%)

Reviewing the obtained results it could revealed that, the generation durations were nearly in the same period during the two years of study but the density of the second year generations were lower than the first year generations due to highness of rate of parasitism. The first generation density was high because of favorable climatic factors and low rate of parasitism. On the second generation, density was the lowest one and its duration was the longest one because of the low temperatures and high rate of parasitism. During the third generation the population density raised because the tree was vigor, the temperature start to rise and the rate of parasitism started to decrease. Finally the population density of the fourth generation was high due to the 
high vigor tree to give the fruit (full of plant sap), also it was the shortest one because of high climatic factors

These results are agree with Benassy (1990), Abdel-Kareim and Awadalla (1998), Abivardi (2001), El-Sherif et al. in North Sinai (2001), Elwan and El-Said (2009) in Egypt and Bakry (2014) in Luxor stated that the P. blanchardii had four overlapping generations per a year.

Table 1. Number and durations of the annual generations of Parlatoria blanchardii on date palm trees at Qaliobiya Governorate (2012-2014).

\begin{tabular}{|c|c|c|c|}
\hline Generations & Data from---- to & Duration in months & Peak nymph / leaflet \\
\hline \multicolumn{4}{|c|}{ First year $2012-2013$} \\
\hline $1^{\text {st }}$ Generation & $\begin{array}{c}\text { From } 1^{\text {st }} \text { July to } 1^{\text {st }} \\
\text { October }\end{array}$ & 3.5 & 848 \\
\hline $2^{\text {nd }}$ Generation & $\begin{array}{l}\text { From mid October to } \\
\text { mid January }\end{array}$ & 3.5 & 267 \\
\hline $3^{\text {rd }}$ Generation & $\begin{array}{c}\text { From } 1^{\text {st }} \text { February to } \\
\text { mid April }\end{array}$ & 3 & 368 \\
\hline $4^{\text {th }}$ Generation & $\begin{array}{l}\text { From } 1^{\text {st }} \text { May to mid } \\
\text { June }\end{array}$ & 2 & 781 \\
\hline \multicolumn{4}{|c|}{ Second year 2013-2014 } \\
\hline 1st Generation & $\begin{array}{l}\text { From } 1^{\text {st }} \text { July to mid } \\
\text { September }\end{array}$ & 3 & 388 \\
\hline $2^{\text {nd }}$ Generation & $\begin{array}{c}\text { From } 1^{\text {st }} \text { October to mid } \\
\text { January }\end{array}$ & 4.5 & 95 \\
\hline $3^{\text {rd }}$ Generation & $\begin{array}{c}\text { From } 1^{\text {st }} \text { February to } \\
\text { mid April }\end{array}$ & 2.5 & 210 \\
\hline $4^{\text {th }}$ Generation & $\begin{array}{c}\text { From } 1^{\text {st }} \text { May to mid } \\
\text { June }\end{array}$ & 2 & 479 \\
\hline
\end{tabular}

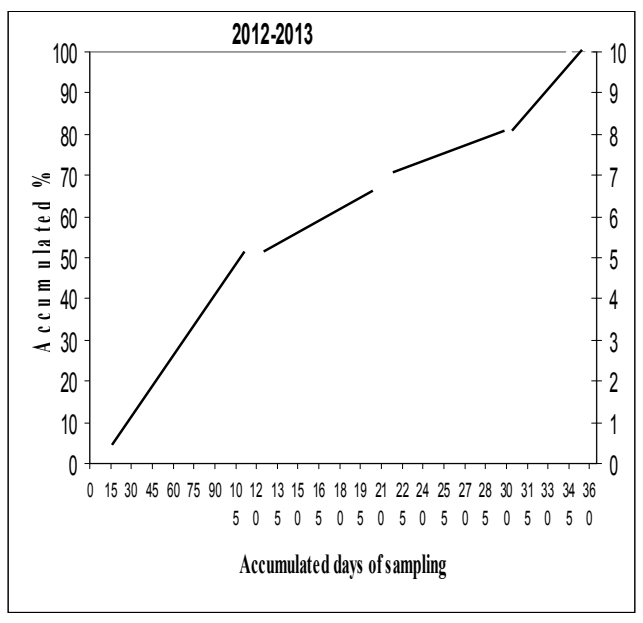

Fig. 3. Number and duration of field generations of Parlatoria blanchardii on date palm according to Jacob (1977) at Qaliobiya Governorate during (2012-2013) .

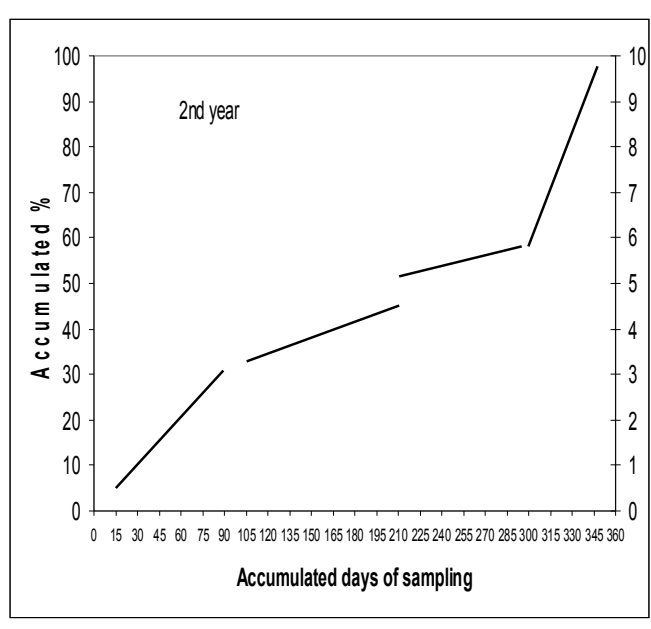

Fig. 4. Number and duration of field generations of Parlatoria blanchardii on date palm according to Jacob (1977) at Qaliobiya Governorate during (2013-2014). 


\section{Seasonal fluctuation of Pteroptrix aegyptica As a mortality biotic factor influencing P.blanchardii population density on date palm trees:}

Laboratory examination of collected date palm leaflets infested by P. blanchardii showed the presence of one Hymenopterous parasitoid; pteroptrix aegyptica belonging to order Hymenoptra, family Aphelinidae. It is highly host specific ecto parasite of date palm scale insect p.blanchardii.

Analysis of data showed in Figs. (5\&6) proved that Pteroptrix aegyptica total population had a dynamic curve with four peaks per a year, during the first year of study they recorded on early August (32 individual/leaflet), early November(12 individual/leaflet), mid December (18 individual/leaflet) and the last peak on mid April (16 individual/leaflet). Besides during the second year of study there were also four peaks recorded on mid August, mid November, early February and mid May with (19, 24, 55\&16 individual/leaflet) respectivly. On the other hand there were three depressions, the first recorded on 1st July with 1individual/leaflet, the second one recorded on mid October with 0 individual/leaflet and the third one was depression period, started from mid May till end of the year with 2individual/leaflet. Also during the second year there were four depressions recorded on mid July, early September, mid December and finally the fourth one was long depressive perriod started from early February till the end of the year of study which decreased gradually from 5 to 1 individual/leaflet.

\section{The parasitic role of Pteroptrix aegyptica as biotic mortality factor influencing $\boldsymbol{P}$. blanchardii population density:}

Data presented in Tables ( 4 and 5 ) and illustrated in Figs. (5 and 6) clearly showed that, the rate of parasitism of Pteroptrix aegyptica had a curve of four generations on $1^{\text {st }}$ August 2012, $1^{\text {st }}$ November, $1^{\text {st }}$ January and mid April 2013 with $1.97,2.45,2.62$ and $1.83 \%$, respectively. During the second year of study the rate of parasitism highly increased and gave three peaks recorded in mid August, mid November, mid January with $11.66,44.44 \& 18.15 \%$ respectively.

On the other hand there were five depressive rate of parasitism recorded on early July $(0.17 \%)$, early September $(0 \%)$, mid October $(0 \%)$, early February $(0.25 \%)$ and early June $(0.15 \%)$. In the second year of investigation there were four depressions recorded on mid July $(0.84 \%)$, mid October (0\%), mid December(2.7\%) finally the fourth one was long period started from mid April till the end of the year decreased to reach $0.35 \%$ These results are agree with, Saad (1980) stated that, in Egypt, P. blanchardii was parasitized upon with the two aphelinid parasitoids Aphytis sp and Aspidiotiphagus lounsburii (Hymenoptera - Aphelinidae) and the parasitism mostly occurred during March, April, June, August and October with 3-4 peaks in 
March, April, mid June and August to mid October. Ibrahem (1999) found also that the seasonal rate of parasitism of Aphytis sp. on Parlatoria blanchardii on date palms at Al-Dhahia locality, Al-Arish region, North Sinai had four peaks per year recorded on mid May, mid August, early November and early December for the first year 1994/1995 and on mid April, mid June, early October and early December during $1995 / 1996$.

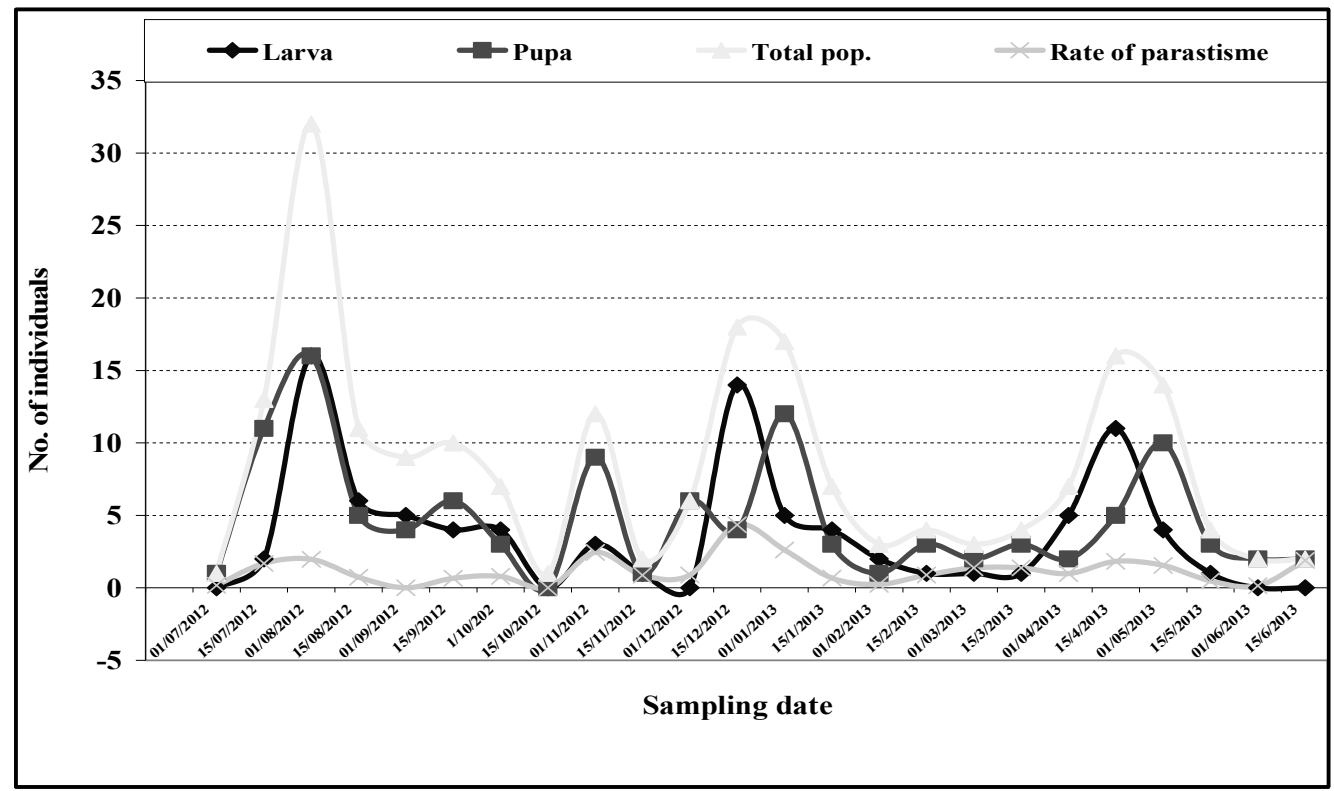

Fig. 5. Seasonal fluctuations of Pteroptrix aegyptica during 2012-2013.

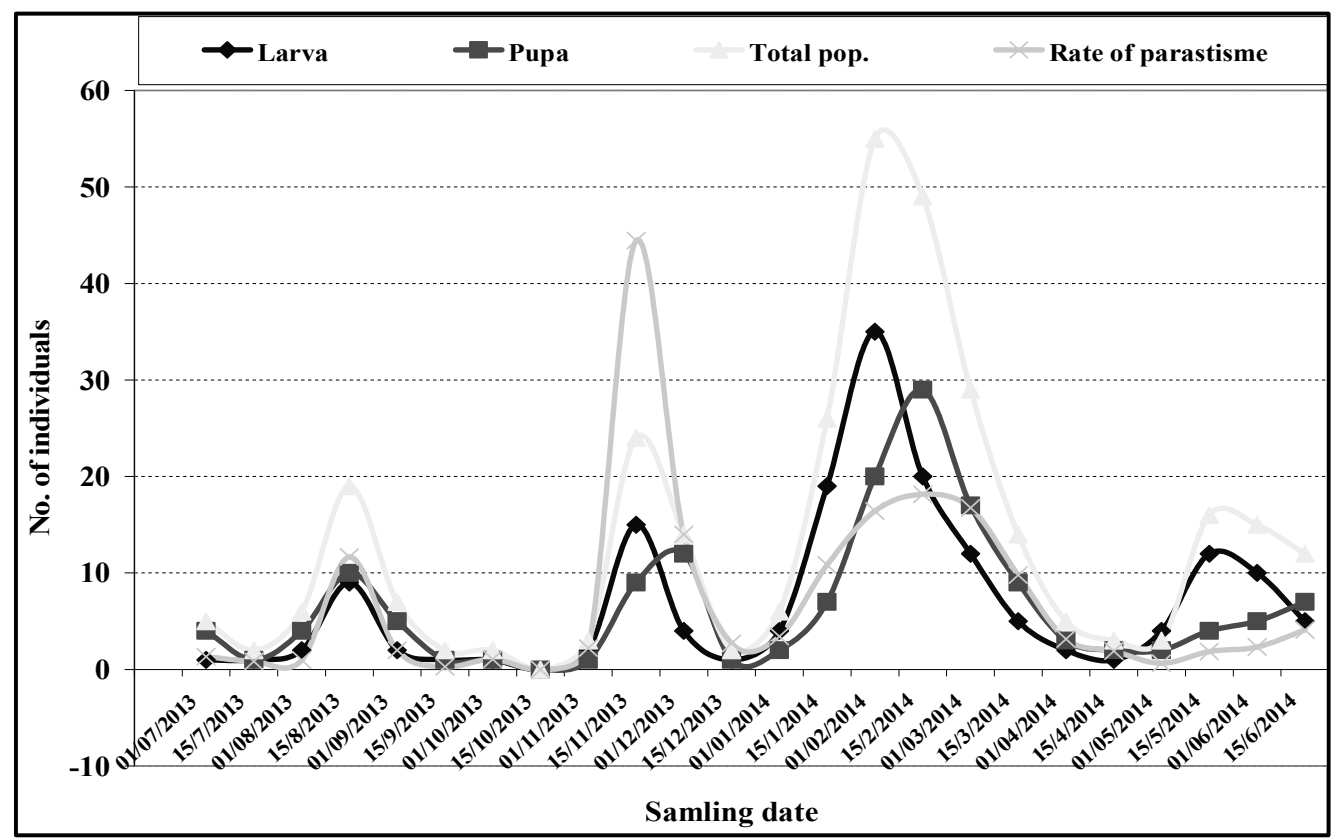

Fig. 6. Seasonal fluctuations of Pteroptrix aegyptica during 2013-2014. 
Finally from previous study of the population fluctuations of the date palm pest Parlatoria blanchardii and its parasitoid pteroptrix aegytica we found that during the first year of investigation the population of the pest was highly increased to reach 19293 insect but the parasitoid population was very low recording 195 per the same year. On the other side during the second year of study, the population of the pest decreased to reach 6477 insect per the second year of study because of the highly increase of the parasitoid population to reach 319 insect for the same year. Accordingly when the population of the parasitoid gives a peak, the population of the pest was low as in the first year of study, or moderate as in the second year of study.

\section{Effect of the climatic factors on Parlatoria blanchardii different stages:}

The effectiveness of abiotic factors on $P$. blanchardii different stages were studied during two studied years (2012-2013 \& 2013-2014) in Qaliobiya governorate as in Tables (4 and 5).

1) Simple correlation: The simple correlation of the different stages of $P$. blanchardii nymph, adult and gravid gave positive highly significant values during the two years of study.

2) Multiple regression: The multiple regression of the different stages showed insignificant effect during the two year of study except the minimum temperature which gave positive significant values on the different stages of $P$. blanchardii during the two years of study.

\section{3) The combined effect of the climatic factors:}

The combined effect of climatic factors on the $P$. blanchardii different stages nymph, adult females and gravid females were significant $(F=67.61,80.62$ \& 62.09) respectively and the explained variance (E.V.) presented (91.02, $92.36 \& 90.3 \%$ ) respectively during the first years of study. Also during the second year of study the combined effect of climatic factor on different stages of the same pest were significant $(F=150.47,43.62 \& 28.32)$ respectively and the explained variance (E. V.) were (95.76, $86.74 \& 80.95 \%)$ respectively. 
Table 2. Results of statistical analysis for simple correlation and multiple regression to investigate the effect of three climatic factors on $P$. blanchardii different stages during the two years of study

\begin{tabular}{|c|c|c|c|c|c|c|c|c|}
\hline \multirow{2}{*}{ Stage } & \multirow{2}{*}{ Variable } & \multicolumn{2}{|c|}{ Simple correlation } & \multicolumn{5}{|c|}{ Multiple Regression } \\
\hline & & $r$ & $\mathrm{P}$ & $b$ & $\mathrm{P}$ & $\mathrm{F}$ & $\mathrm{P}$ & EV \\
\hline \multicolumn{9}{|c|}{ First year (2012-2013) } \\
\hline \multirow{3}{*}{ Nymph } & Tmax & 0.75323 & 0.0001 & 31.32004 & 0.0105 & \multirow{3}{*}{67.61} & \multirow{3}{*}{0.0001} & \multirow{3}{*}{91.02} \\
\hline & Tmin & 0.9351 & 0.0001 & 0.40097 & 0.0001 & & & \\
\hline & $\mathrm{RH}$ & 0.69824 & 0.0001 & -24.9983 & 0.0166 & & & \\
\hline \multirow{3}{*}{ Adult } & Tmax & 0.65786 & 0.0005 & -13.9325 & 0.039 & \multirow{3}{*}{80.62} & \multirow{3}{*}{0.0001} & \multirow{3}{*}{92.36} \\
\hline & Tmin & 0.95023 & 0.0001 & 0.29698 & 0.0001 & & & \\
\hline & $\mathrm{RH}$ & 0.67594 & 0.0003 & 9.80128 & 0.0867 & & & \\
\hline \multirow{3}{*}{ Gravid } & Tmax & 0.69325 & 0.0002 & -17.44 & 0.0405 & \multirow{3}{*}{62.09} & \multirow{3}{*}{0.0001} & \multirow{3}{*}{90.3} \\
\hline & Tmin & 0.93734 & 0.0001 & 0.30205 & 0.0001 & & & \\
\hline & $\mathrm{RH}$ & 0.71972 & 0.0001 & 0.30205 & 0.038 & & & \\
\hline \multicolumn{9}{|c|}{ Second year (2013-2014) } \\
\hline \multirow{3}{*}{ Nymph } & Tmax & 0.38063 & 0.0665 & -3.90222 & 0.397 & \multirow{3}{*}{150.47} & \multirow{3}{*}{0.0001} & \multirow{3}{*}{95.76} \\
\hline & Tmin & 0.96744 & 0.0001 & 0.63549 & 0.0001 & & & \\
\hline & $\mathrm{RH}$ & 0.45767 & 0.0245 & 0.5698 & 0.8908 & & & \\
\hline \multirow{3}{*}{ Adult } & Tmax & 0.48227 & 0.017 & 6.00401 & 0.1026 & \multirow{3}{*}{43.62} & \multirow{3}{*}{0.0001} & \multirow{3}{*}{86.74} \\
\hline & Tmin & 0.92034 & 0.0001 & 0.26671 & 0.0001 & & & \\
\hline & $\mathrm{RH}$ & 0.5186 & 0.0094 & -5.5952 & 0.0948 & & & \\
\hline \multirow{3}{*}{ Gravid } & Tmax & 0.75692 & 0.0001 & -2.12701 & 0.5464 & \multirow{3}{*}{28.32} & \multirow{3}{*}{0.0001} & \multirow{3}{*}{80.95} \\
\hline & Tmin & 0.78831 & 0.0001 & 0.09788 & 0.0023 & & & \\
\hline & $\mathrm{RH}$ & 0.8124 & 0.0001 & 5.05419 & 0.1243 & & & \\
\hline
\end{tabular}

\section{REFERENCES}

1. Abdel-Kareim.A.I.and S.S. Awadalla. 1998. Population dynamic of the date palm scale Parlatoria blanchardii (Targioni- Tozzetti) (Homoptera: Diaspididae). J. Agric. Sci. Mansoura Univ., 23 (7): 3431-3441 pp.

2. Abivardi, C. 2001. Iranian entomology: An Introduction. Vol. 1: Faunal Studies, P. 1-444; Vol. 2: App. Entomol, P. 445-1033.- Springer,Berlin, Heidelberg, New York.

3. Avidov, Z. and I. Harpaz. 1969. Plant pests' of Israael University press Jerusalem, 549 pp. (c.f. R.A.E., 1970, 58:3).

4. Bakry, M.M.S 2014. Studies on the white date palm scale insect, Parlatoria blanchardii (Targ.) infesting date palm trees in Luxor Governorate. Ph. D. Thesis, Fac. Agric. Minia. Univ., 288 pp.

5. Benassy, C. 1990. Date palm. In: D. Rosen (Ed.), Armored scale insects,tneir biology, natural enemies and control. Vol. 4B. World Crop pests. Elsevier, Amsterdam, the Netherland: 585-591 pp.

6. Blumberg, D. 2008. Date palm Arthropod pests and their Management in Israel. Phytoparasitica 36(5): 411-448 pp. 
7. El-said, M.I. 2000. Survey of date palm insects in North Sinai with special reference to the ecology and biology of the species, Parlatoria blanchardii (Targioni- Tozzetti), super family Coccoidea M. Sc. Thesis, Fac. Agric., Cairo Univ., $97 \mathrm{pp}$.

8. El- sayed, M.E.T. 2007. Bio- ecological studies on some armored scale insect and their parasitoids. Ph. Thesis, Fac. Agric., Alexandria Univ. 131 pp.

9. El-Sherif, S.I.; E.A. Elwan and M.I.E. Abd-El-Razik. 1998. Insects pests of date palm trees in northern Sinai Egypt, First International Conference on Date Palm (Al-Ain, UAE, March 8-10) 255-262 pp.

10. El-Sherif, S.I.; E.A. Elwan and M.I.E. Abd-El-Razik. 2001. Ecological observations on the date palm parlatoria scale, Parlatoria blanchardii (Targioni- Tozzettii) (Homoptera diaspididae) in north Sinai, Egypt. Second International Conference on date palms (Al-Ain, UAE, March 25-27).

11. Elwan, E.A.and M.I. El-Said. 2009. Biological studies on the parlatoria date scale, Parlatoria blanchardii (Targioni- Tozzettii) under laboratory condition. Arab J. Plant Prot., October. Vol. 27, special Issue (Supplement): A-45 pp.

12. Eraki, M.M. 1998. Ecological studies on some scale insects infesting date palm trees. Ph.D. Thesis, Fac. of Agric., Al-Azhar Univ., Egypt 127 pp.

13. Hussain, A. E. 1996. Comparative study on distribution and seasonal abundance of date scale, Parlatoria blanchardii (Targioni- Tozzettii). Population in Giza and Bahria Oases regions. Bull. Ent. Soc. Egypt., 74:54-60 pp.

14. Ibrahim, T.M. 1999. Studies on some pests infesting date palm trees. M. Sc. Thesis, Fac. Agric., Zagazig Univ., Egypt, 220 pp.

15. Jacob, N. 1977. Un mode mathematic pentra stabilirea limitelor economic de toleranta a atacului moliilor fructelor inlupte integrate. Analele I.C.P.P.15.

16. Kehat, M.; E.Swirski; D, Blumberg and S. Greenberg. 1974. Integrated control of date-palm pests in Israel Phytoparasitica, 2(2): 141-149 pp. (c.f. R.A.E., 64(4): 1988. 1979).

17. Loutfy, I.E. 2010. Degradation of date palm Trees and Date Production in Arab Countries: Causes and Potential Rehabilitation. Australian J. Bas. Appl. Sci., (8): 3998-4010 pp.

18. Orphanides, G. M. 1982. Biology of the California red scale, Aonidiella aurantii (Maskell) (Homoptera, Diaspididae), and its seasonal availability for parasitization by Aphytis spp in Cyprus. (Biological citation): Boll. Entomol. Agraria Filippo Silvestri, 39: 203-212 pp.

19. Saad, A.G.A. 1980. Studies on date palm trees insects belonging to Coccoidea in Egypt. Ph. D. Thessis, Fac. Agric., Al-Azhar Univ., Cario, Egypt. 


\section{التغير ات الموسمية لحشرة النخيل القشرية التى تصيب أثجار النخيل و الطفيل المصاحب لها بتيرو بتركس ايجيبتكا فى محافظة القليوبية}

\section{سحر على عطية}

$$
\text { معهد بحوث وقاية النباتات، مركز البحوث الزراعية، الدقي، الجيزة. }
$$

يصاب النخيل بالعديد من الافات فى محافظة القليوبية من اهمها حشرة النخيــل القثـــرية ، حيث تصيب الحشرة كل أجزاء أثنجار خيل البلح و تسبب لها الضعف التام و نقص المحصول كما و

تختص الدر اسة بدر اسة التغير ات الموسمية للافة وتعريف ودر اسة الطفيل المصــاحب لهــا.

خلال عامين متتالين و معرفة الوقت الامتل لمكافحة هذة الافة.

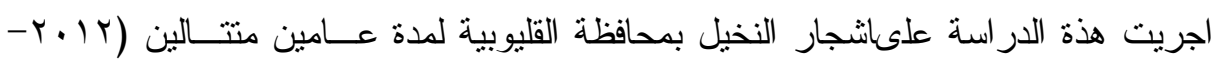

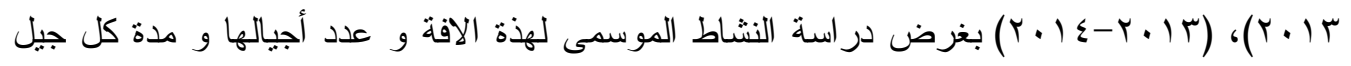

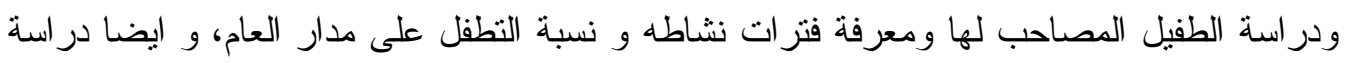
تاثير عو امل الطقس السائدة فى تلك المنطقة على نشاط الحشرة. أوضحت النتائج أن حشرة النخيل القشرية تتو اجد على أشجار النخيل طول العام و لها أربعة أجيــال

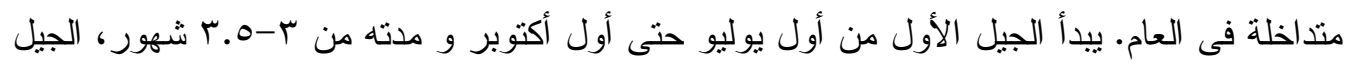

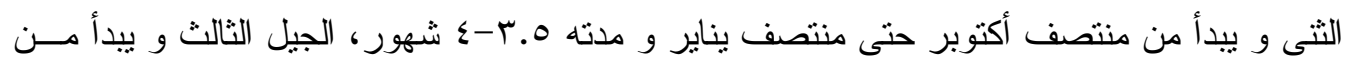

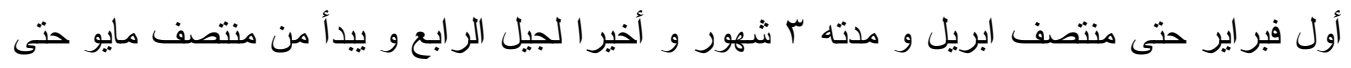
منتصف يونيه و مدته شهرين خلال كل عام من عامى الدر اسة. وجد أن الطفيل المصاحب للافة هو طفيل بتيروبتركس له أربع فتز ات نشاط فئ فئ السنة و كان كان أعجللى فترة نشاط لها فى فصل الصيف فى العام الاول من الدراسة و فى فصل الثتاء فى العام الثانى مسنـ

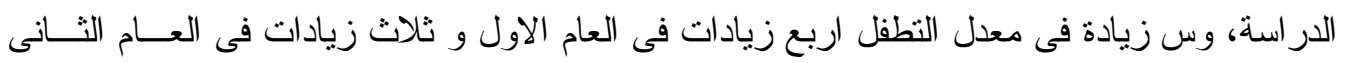
من الدراسة.

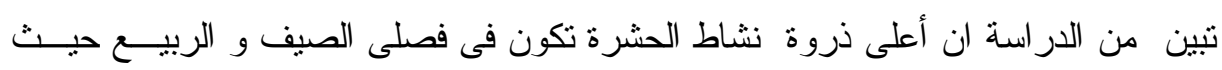

تكون درجتى الحر ارة الدنيا و العليا و الرطوبة النسبية عالية و مناسبة لزيادة نشاط الحشرة.

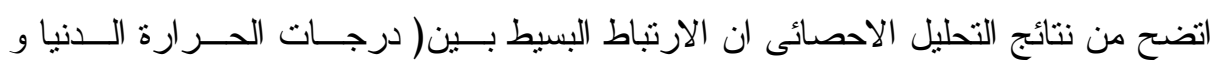

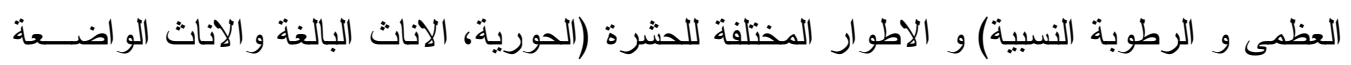

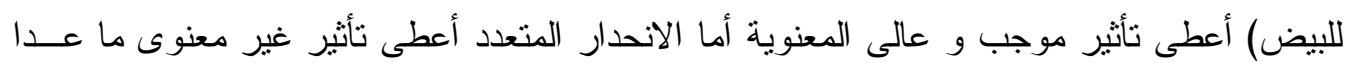

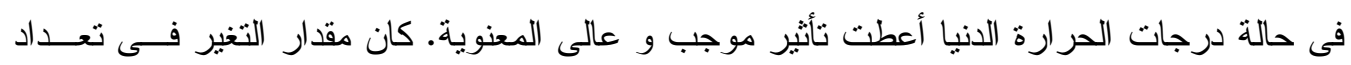

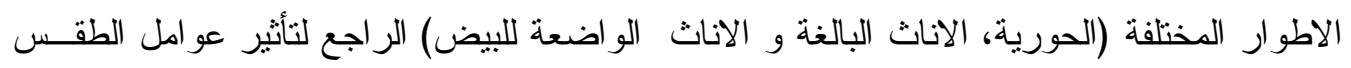

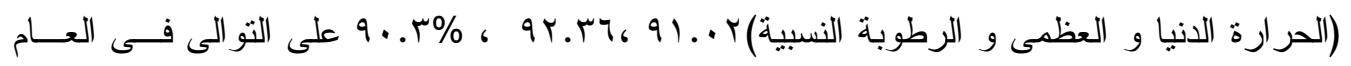

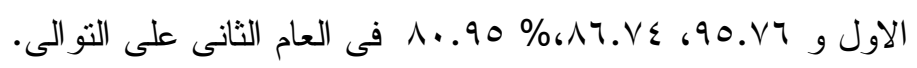

